\title{
DISTRIBUTION OF HEAVY METALS CONCENTRATIONS IN SOILS AROUND THE INTERNATIONAL ATHENS AIRPORT (GREECE). AN ASSESSMENT ON PRELIMINARY DATA
}

\author{
Massas I. ${ }^{1}$, Ioannou D. ${ }^{1}$, Kalivas D. ${ }^{1}$ and Gasparatos D. ${ }^{2}$ \\ ${ }^{1}$ Agricultural University of Athens, Laboratory of Agricultural Chemistry and Soil Science, Iera \\ Odos 75,11855,Athens,massas@aua.gr,dioannou@aua.gr,kalivas@aua.gr \\ ${ }^{2}$ Aristotele University of Thessaloniki, Laboratory of Soil Science, gasparatos@agro.auth.gr
}

\begin{abstract}
Soils are receptors of atmospheric metal depositions and hence reliable indicators of pollution phenomena, especially for cases that potential site specific pollution sources are detected in terrestrial ecosystems. The purpose of this study was to assess the distribution of $\mathrm{Cu}, \mathrm{Zn}, \mathrm{Fe}, \mathrm{Mn}, \mathrm{Ni}, \mathrm{Cr}, \mathrm{Pb}$, and Ba concentrations in soils nearby the International Athens Airport "El. Venizelos", in Attica, Greece. Total metal concentrations were determined in 86 topsoil aqua regia extracts and the median values for $\mathrm{Cu}, \mathrm{Zn}, \mathrm{Fe}, \mathrm{Mn}, \mathrm{Ni}, \mathrm{Cr}, \mathrm{Pb}$, and Ba concentrations were 23, 81, 22x10 , 497, 87, 74, 75, and $423 \mathrm{mg} \mathrm{kg}^{-1}$ respectively. Though median values are not considered as high, the $90^{\text {th }}$ percentile concentration values for some metals are high, indicating possible soil enrichment by these metals. A tendency for increased concentrations of $\mathrm{Zn}$ and $\mathrm{Cr}$ along the north-south axis and of $\mathrm{Pb}, \mathrm{Cu}$ and $\mathrm{Ni}$ at the northern part of the studied area was also observed. As a first approach to discriminate between natural and anthropogenic metal contributions in the soils of the area, the obtained preliminary data were subjected to cluster analysis and to the evaluation of metals Enrichment Factors (EFs). Both EF values and cluster analysis results suggested secondary $\mathrm{Pb}, \mathrm{Cu}$ and $\mathrm{Zn}$ site specific accumulation in the soils of the studied area.

Keywords: Soil Characteristics, Heavy metals, Airport, Enrichment Factor, Cluster Analysis.
\end{abstract}

\section{Пврі́ $\lambda \eta \psi \eta$}

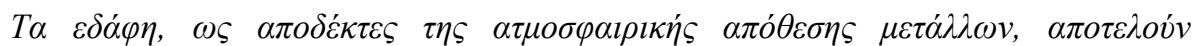

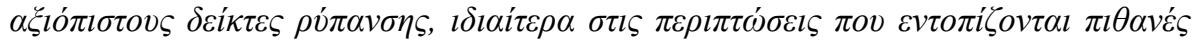

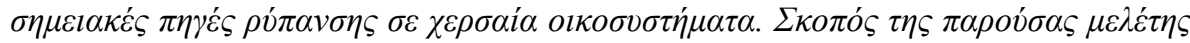

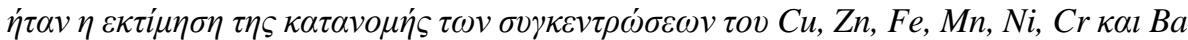

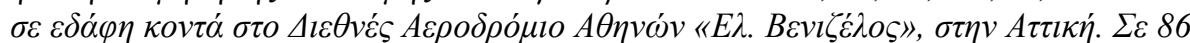

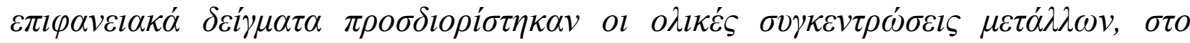

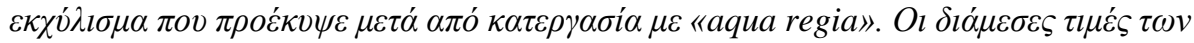

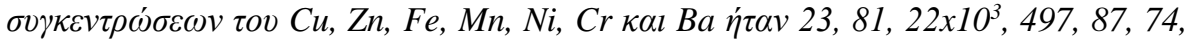

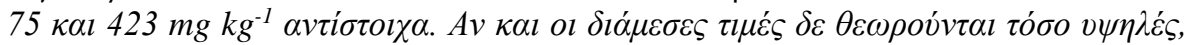

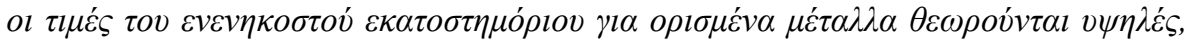

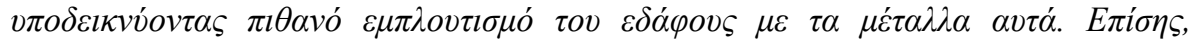




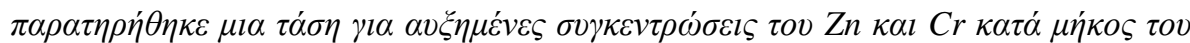

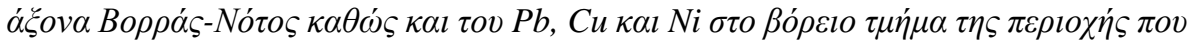

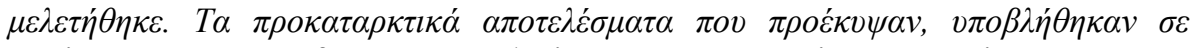

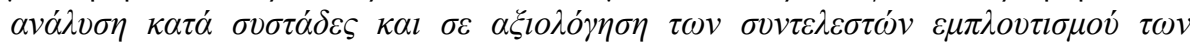

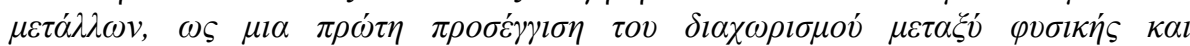

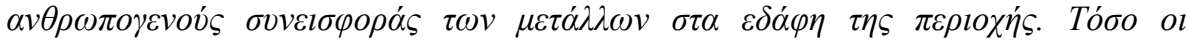

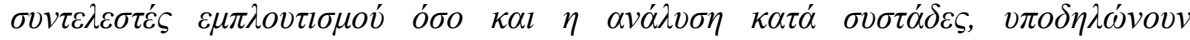

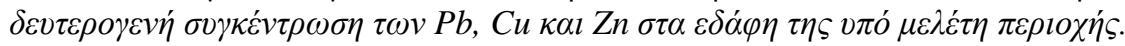

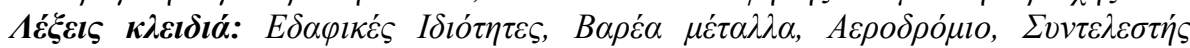

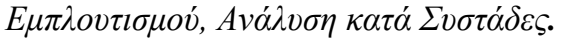

\section{Introduction}

Heavy metals occur naturally as chemical elements in the earth's crust and surface soils in varying concentrations (Alloway and Ayres, 1997). Total metal contents in soils are directly related to the nature of the parent material they are derived from (Swaine and Mitchell, 1960). Soils in urban and rural areas may become contaminated by accumulation of heavy metals through natural processes and/or human practices that may be high enough to pose risk to human health, plants, animals, and ecosystems (D'amore et al., 2005). In terrestrial ecosystems many kinds of interactions between solids, liquids, gases and the biota take place as geochemical and biological processes (Giannakopoulou et al., 2012) that evolved and affected by anthropogenic factors such as agricultural practices, industrial activities, waste treatments etc. (Kabata-Pendias, 2001).

Increased heavy metal concentrations in soils have been recorded for many industrial, urban, rural, and mixed land uses areas (Srinivasa Gowd et al., 2010; Bretzel and Calderisi, 2006; Massas et al., 2009; Koulourasis et al., 2009). Considering that soils are not a renewable resource and that heavy metals do not biodegrade but accumulate in soils, it is necessary to monitor soil metal concentrations to prevent pollution situations and to propose remediation actions if necessary.

There are only few reports on the distribution of heavy metals in soils in the vicinity of international airports (Table 1). Thus, the purpose of this study was: (1) to determine the actual total concentration of $\mathrm{Cr}, \mathrm{Ni}, \mathrm{Zn}, \mathrm{Pb}, \mathrm{Cu}, \mathrm{Co}, \mathrm{Mn}, \mathrm{Ba}$, and $\mathrm{Fe}$ in soils around the International Athens airport area (2) to assess the spatial distribution of metals and (3) to discuss on possible relations between metals concentrations and soil properties.

\section{Materials and Methods}

\subsection{Study area and sampling}

The study area and the sampling sites are presented in Figure 1. Athens International Airport "El. Venizelos", is located in Mesogaia region, Eastern Attica, Greece, approximately 25 kilometers northeast of Athens. The climate of the area is typical subtropical Mediterranean, with prolonged hot and dry summers succeeded by considerably mild and wet winters. The mean annual precipitation is approximately $400 \mathrm{~mm}$, while snowfall is rare. The drought period usually begins in May and lasts until October. The daily mean temperature ranges between $27^{\circ} \mathrm{C}$ during the summer months and $11^{\circ} \mathrm{C}$ during the winter months (Papathanasiou et al., 2013a, b). Geologically, the study area is part of the Attico-Cycladic Massif. It is generally flat with low hills and consists of alluvial and diluvial deposits.

El. Venizelos airport operates since March 2001 and according to air traffic statistical data of the year 2013 has been ranked as the $35^{\text {th }}$ airport in Europe. In 2014 the airport handled 154.530 aircraft movements, 15.196 .369 passengers and 77.337.956 tons of cargo (http//www.aia.gr). The Municipalities of Spata, Koropi, Artemis and Markopoulo are located nearby. The airport facilities and infrastructure occupy an area of approximately $10 \mathrm{~km}^{2}$ surrounded by agricultural land. Most of this land is covered by vineyards, but vegetable, olive and fruit tree cultivations are also present. 
Topsoil samples (0-10 cm depth) were collected from the region around El. Venizelos airport during the summer of 2013. In order to obtain a distribution pattern of heavy metals concentrations in the soils of the area, a grid-type sampling scheme (cell size 1000x1000 m or 500x500 m in some cases) was followed, oriented by the presence of the airport. At every sampling site, three subsamples from $100 \times 100 \mathrm{~cm}$ surface area were obtained and mixed to make each of the 86 bulk soil samples.

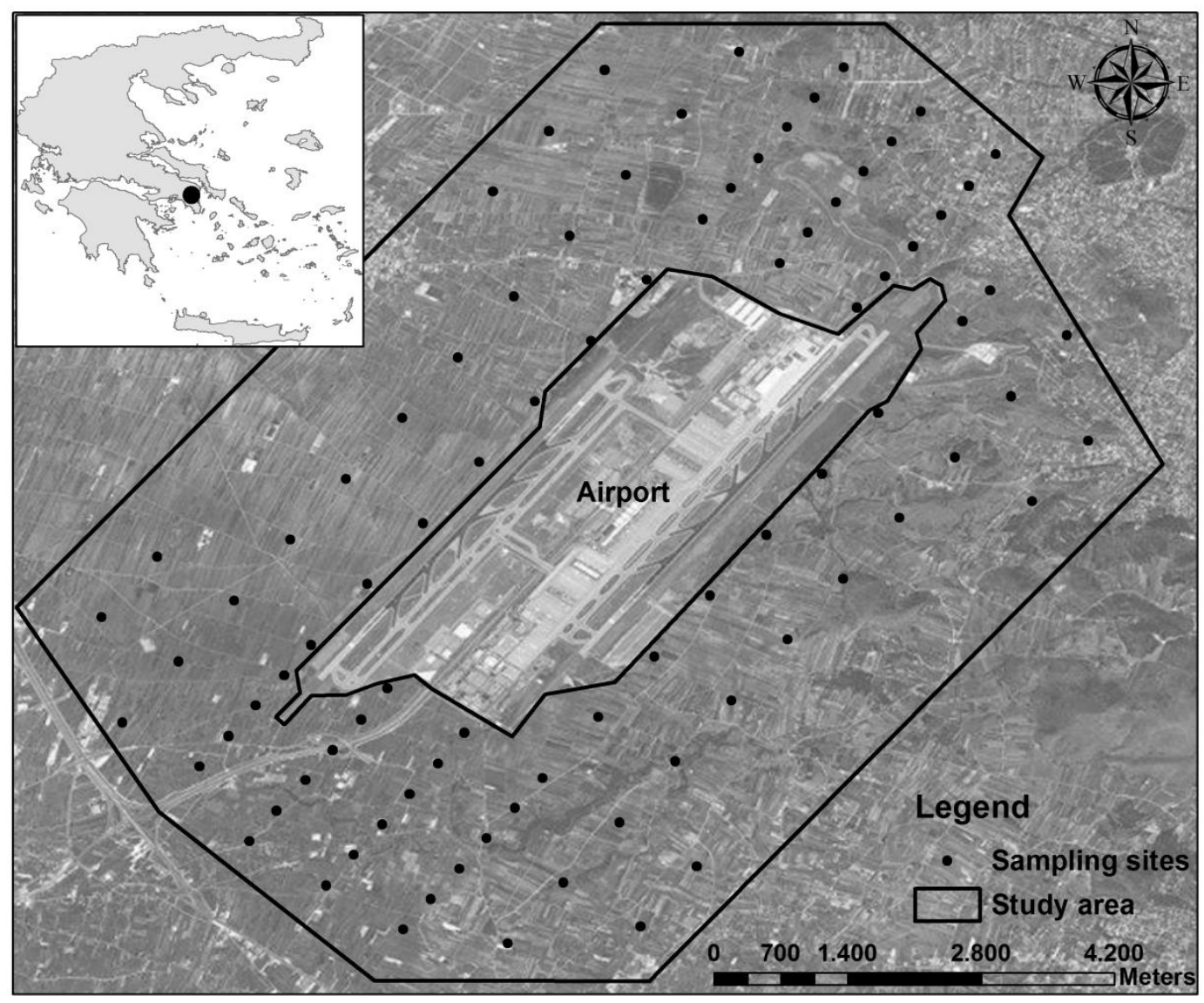

Figure 1 - Studied area and sampling sites.

\subsection{Sample preparation and analysis}

The soil samples were transferred to the laboratory in polyethylene bags, air-dried and sieved through a 2-mm sieve. The mechanical composition of the samples was determined by the Bouyoucos hydrometer method (Bouyoucos, 1951), while the organic matter content by the Walkley-Black procedure (Nelson and Sommers, 1982). Soil $\mathrm{pH}$ was determined in 1:1 v/w soilwater ratio slurries by the use of standard glass/calomel electrodes. The $\mathrm{CaCO}_{3}$ equivalent percentage was estimated by measuring the evolved $\mathrm{CO}_{2}$ following $\mathrm{HCl}$ dilution.

To obtain "pseudo-total" metal concentrations, the soil samples were digested with aqua regia (Gasparatos and Haidouti, 2001). "Pseudo-total" expression accurately describes the metal concentrations determined in aqua-regia extracts, because aqua-regia digestion does not completely destroy silicates (Facchinelli et al., 2001). However, in the text of this study, the term "total" is used for simplicity.

All metal concentrations were determined by atomic adsorption spectrophotometer Varian spectra A300. The calibration standards were prepared in aqua-regia matrix which was used for the soil 
samples. A control sample was analyzed for every ten samples, and reproducibility was tested by reanalyzing $30 \%$ of the samples. Analytical precision, estimated as relative standard deviation, ranged from $3 \%$ to $5 \%$ depending on the metal.

\subsection{Enrichment factor (EF)}

Table 1 - Total metal concentrations in soils close to international airports.

Heavy metal enrichment factors (EFs) for the soil samples were calculated as described by Massas et al. (2010) and the following equation was used:

\begin{tabular}{|l|l|l|l|l|l|l|l|l|l|l|l|}
\hline \multicolumn{1}{|c|}{ Location } & $\mathbf{C u}$ & $\mathbf{Z n}$ & $\mathbf{M n}$ & $\mathbf{N i}$ & $\mathbf{C r}$ & $\mathbf{P b}$ & $\mathbf{B a}$ & $\mathbf{F e}$ & References \\
\hline $\begin{array}{l}\text { Shanghai } \\
\text { Airport } \\
\text { (China) }\end{array}$ & 25 & 186 & - & 44 & 157 & 81 & - & - & $\begin{array}{l}\text { Rao } \text { et al. }, \\
\text { mg g }\end{array}$ \\
\hline $\begin{array}{l}\text { Pretoria } \\
\text { Wonderboo } \\
\text { m Airport } \\
\text { (South } \\
\text { Africa) }\end{array}$ & 98 & 88.9 & 1320 & & 820 & 98.1 & - & 91.3 & $\begin{array}{l}\text { Olowoyo } \text { et } \\
\text { al., } 2013\end{array}$ \\
\hline $\begin{array}{l}\text { Delhi (IGI) } \\
\text { Airport } \\
\text { (India) }\end{array}$ & 21 & 97 & 391 & 44.2 & 127 & 37.5 & - & 4.38 & $\begin{array}{l}\text { Ray } \text { et al., } \\
\text { 2012 }\end{array}$ \\
\hline $\begin{array}{l}\text { Queen Alia } \\
\text { Airport, } \\
\text { (Jordan) }\end{array}$ & 3.0 & 51.4 & & & 16.9 & 60.2 & - & 0.05 & $\begin{array}{l}\text { Al-Khashman } \\
\text { \& Shawabkeh, } \\
\text { 2009 }\end{array}$ \\
\hline $\begin{array}{l}\text { Athens } \\
\text { Airport } \\
\text { (Greece) }\end{array}$ & 27 & 95.2 & 562.7 & 92.1 & 79.8 & 79 & 442 & 22.4 & This study \\
\hline
\end{tabular}

$\mathrm{EF}=$ Cit $/$ Ait

where Cit, is the total metal concentration in the ith sampling site and Ait is the target metal A value of the Dutch guidelines system (Netherlands Ministry of Housing, Physical Planning and Environment (Netherlands M.H.P.P.E., 2000), obtained by adjusting the standard Atv value of the system for the ith sampling site according to the equation:

$\mathrm{Ai}=\operatorname{Atv} \times[\{\mathrm{a}+(\mathrm{b} \times$ \%clay $)+(\mathrm{c} \times$ \%organic matter $)\} /\{(\mathrm{a}+(\mathrm{b} \times 25)+(\mathrm{c} \times 10)\}]$

where:

Atv $=$ standard A value of the metal in the Dutch guidelines system (Netherlands M.H.P.P.E., 2000)

$\%$ clay $=$ percentage clay (grain size $<2 \mathrm{~mm}$ ) in the soil to be assessed

$\%$ organic matter $=$ organic matter percentage $(\mathrm{w} / \mathrm{w})$ in the soil to be assessed.

$\mathrm{a}, \mathrm{b}, \mathrm{c}=$ metal dependent constants for each metal

EF values > 1 may be considered as possible soil enrichment.

\subsection{Statistical Analysis and GIS}

The descriptive statistical parameters, correlation analysis and cluster analysis were carried out by using the statistical software STATISTICA for Windows (StatSoft, Inc., USA, 1995, Version 7).

Spatial distributions of total metal concentrations in the soils of the tested area were visualized on maps produced by the ArcMap V9.3 software. The Geostatistical Analyst extension was used to 
interpolate values between the sampling sites and to create interpolated surfaces by the Inverse Distance Weighted method.

\section{Results}

\subsection{Soil properties}

The soils of the studied area were developed mainly on alluvial deposits and their physicochemical key characteristics are presented in Table 2 . The soils show light to medium texture as sand content ranged from $28.00-85.40 \%$ and clay content ranged from 8.00 to $42.60 \%$. The $\mathrm{pH}$ does not vary much and is slightly basic (mean value=7.95) suggesting sub alkaline conditions and low metal mobility in the tested soils. Calcium carbonate equivalent ranges from 2.7 to $54.4 \%$, with an average value of $19 \%$. High percentages of carbonates in soils are usually related to low bio-availability of heavy metals. Organic matter content highly fluctuated between traces and $21.06 \%$, but most of the samples are poorly or moderately supplied by organic matter. These properties point to soils of adequate drainage that secure sufficient soil aeration and oxidizing conditions. Sand, clay, silt, organic matter, calcium carbonate equivalent content values and $\mathrm{pH}$ values are normally distributed, pointing to minimal site specific system disturbance.

Table 2 - Descriptive statistics of selected physicochemical properties of the studied soils (N=86).

\begin{tabular}{|l|l|l|l|l|l|l|}
\hline & $\begin{array}{c}\text { Sand } \\
(\boldsymbol{\%})\end{array}$ & \multicolumn{1}{|c|}{$\begin{array}{c}\text { Silt } \\
(\boldsymbol{\%})\end{array}$} & $\begin{array}{c}\text { Clay } \\
(\boldsymbol{\%})\end{array}$ & $\begin{array}{c}\text { Org. } \\
\text { matter } \\
(\boldsymbol{\%})\end{array}$ & $\begin{array}{c}\text { CaCO3 eq. } \\
(\boldsymbol{\%})\end{array}$ & $\begin{array}{c}\text { pH } \\
(\mathbf{1 : 1})\end{array}$ \\
\hline Mean & 52.6 & 22.7 & 24.7 & 2.53 & 19.0 & 7.95 \\
\hline Median & 52.8 & 23.5 & 24.3 & 2.24 & 19.8 & 7.96 \\
\hline Min. & 28.0 & 2.6 & 8.0 & traces & 0.4 & 7.02 \\
\hline Max. & 85.4 & 34.8 & 42.6 & 21.06 & 54.4 & 8.69 \\
\hline $\begin{array}{l}10^{\text {th }} \\
\text { percentile }\end{array}$ & 40.0 & 14.0 & 15.5 & 1.01 & 2.7 & 7.64 \\
\hline $\begin{array}{l}90^{\text {th }} \\
\text { percentile }\end{array}$ & 63.4 & 30.6 & 32.9 & 3.47 & 33.2 & 8.25 \\
\hline SD & 9.6 & 6.5 & 6.7 & 2.38 & 11.8 & 0.26 \\
\hline CV\% & 18.2 & 28.6 & 27.0 & 94.12 & 61.8 & 3.30 \\
\hline
\end{tabular}

\subsection{Total metal concentrations}

The descriptive statistics of the total $\mathrm{Cu}, \mathrm{Zn}, \mathrm{Fe}, \mathrm{Mn}, \mathrm{Ni}, \mathrm{Cr}, \mathrm{Pb}$, and $\mathrm{Ba}$ concentrations are presented in Table 3. Though the mean total metal concentrations fall within the normal range for natural soils or for soils of low metal enrichment, the $90^{\text {th }}$ percentile and maximum values indicate that in some sampling sites (not necessary the same for all metals) concentration values exceed the reference "A values" or even the test "B values" of the Dutch System (Netherlands M.H.P.P.E., 2000). These increased metal concentrations, especially of $\mathrm{Pb}, \mathrm{Cu}$ and $\mathrm{Zn}$, point to secondary metal accumulation in the soils of the area, other than the presence of metals in soils due to soil formation processes. The observed high Ni mean total concentration is commonly detected in Greek soils and attributed to the soils' parent material. However, some soil samples showed clear indications of Ni enrichment. 
Table 3 - Descriptive statistics for the total concentrations of the studied metals of the soils all around El. Venizelos airport $(\mathrm{N}=86)$.

\begin{tabular}{|l|l|l|l|l|l|l|l|l|}
\hline & \multicolumn{1}{|c|}{$\mathbf{C u}$} & \multicolumn{1}{|c|}{$\mathbf{Z n}$} & \multicolumn{1}{|c|}{$\mathbf{M n}$} & \multicolumn{1}{|c|}{$\mathbf{~ i r}$} & $\mathbf{P b}$ & $\mathbf{B a}$ & $\mathbf{F e}^{*}$ \\
\hline & & & & $\mathbf{m g ~ k g}^{-1}$ & & & & \\
\hline Mean & 27.02 & 95.21 & 562.72 & 92.13 & 79.77 & 78.96 & 442.53 & 22.39 \\
\hline Median & 23.25 & 81.00 & 497.00 & 86.90 & 74.18 & 74.90 & 422.75 & 21.71 \\
\hline Min. & 7.95 & 33.50 & 223.00 & 34.60 & 31.00 & 53.30 & 72.00 & 78.45 \\
\hline Max. & 129.05 & 518.00 & 1491.00 & 177.10 & 154.35 & 271.20 & 1171.00 & 44.82 \\
\hline $\begin{array}{l}10^{\text {th }} \\
\text { percentile }\end{array}$ & 17.70 & 61.50 & 363.00 & 60.35 & 52.90 & 62.35 & 257.50 & 15.45 \\
\hline $\begin{array}{l}90^{\text {th }} \\
\text { percentile }\end{array}$ & 33.70 & 130.50 & 860.00 & 133.10 & 108.80 & 96.15 & 649.50 & 29.30 \\
\hline SD & 16.66 & 56.59 & 232.17 & 28.75 & 24.35 & 26.24 & 174.155 & 62.00 \\
\hline CV\% & 61.66 & 59.43 & 41.26 & 31.20 & 30.53 & 33.23 & 39.35 & 27.69 \\
\hline
\end{tabular}

*: Fe concentration in $\mathrm{mg} \mathrm{g}^{-1}$

\section{Discussion}

\subsection{Distribution of metals}

The interpolated studied area covered a land of $48 \mathrm{~km}^{2}$ (including the airport). In Figures 2 and 3, the distribution of $\mathrm{Pb}, \mathrm{Ni}, \mathrm{Cr}, \mathrm{Ba}, \mathrm{Cu}, \mathrm{Zn}, \mathrm{Mn}$ and $\mathrm{Fe}$ total concentrations around the airport is presented. Not a clear unique pattern for the distribution of all metals can be detected. Spots of higher $\mathrm{Pb}$ and $\mathrm{Cu}$ concentrations are observed in the northern part of the studied area. Ni also shows a distribution pattern similar to that of $\mathrm{Pb}$ and $\mathrm{Cu}$, while for $\mathrm{Zn}$ a south to north accumulation in the soils appears. Increased $\mathrm{Cr}, \mathrm{Ba}$ and $\mathrm{Mn}$ concentrations observed in the western part though for $\mathrm{Cr}$ a north to south distribution is also apparent. Finally, the higher Fe concentration is clearly present in the south-west of the area. The interpolated maps that visualize the distribution of total metal concentrations in the soils around the El. Venizelos airport, can serve to relate the distribution pattern of each metal to specific potential metal sources. However, any discussion on the potential sources of the studied metals based on their distribution patterns in soils around the airport is beyond the scope of this preliminary assessment.

\subsection{Enrichment Factors}

Enrichment Factor (E.F.), as a soil pollution index that is calculated by metal concentration values normalized for clay and organic matter content of the soils, may provide a more precise approach to the data. The mean $\mathrm{EF}$ values for $\mathrm{Pb}, \mathrm{Cu}, \mathrm{Zn}, \mathrm{Ni}, \mathrm{Cr}$ and $\mathrm{Ba}$ are 1.03, 0.86, 0.75, 2.68, 0.80 and 2.29 respectively, indicating no or minor or moderate soil pollution, depending on the metal. Mean EF values suggest $\mathrm{Ni}$ and $\mathrm{Ba}$ accumulation in the soils of the area. However, the reference "A values" of the Dutch system (Netherlands M.H.P.P.E., 2000) that were used for the calculation of Ni and Ba $\mathrm{EFs}$ are lower than $\mathrm{Ni}$ and $\mathrm{Ba}$ background concentrations in most Greek soils, and this is probably the main reason for the high $\mathrm{Ni}$ and Ba EFs observed in the soils of the studied area (Geochemical Atlas of Europe, 2005). In Figure 4 the median, the $10^{\text {th }}$ and $90^{\text {th }}$ percentiles and the minimum and maximum EF values of the six metals are presented. Though median EF values are low (with the exception of the high $\mathrm{Ni}$ and $\mathrm{Ba} \mathrm{EF}$ median values for reasons discussed earlier) the $90^{\text {th }}$ percentile and the maximum $\mathrm{EF}$ values for $\mathrm{Pb}, \mathrm{Cu}$ and $\mathrm{Zn}$ indicate site specific soil enrichment by these metals. This argument is further supported by the fact that $\mathrm{Pb}, \mathrm{Cu}$ and $\mathrm{Zn} \mathrm{EF}$ values do not follow a normal distribution pattern (Kolmogorov-Smirnov \& Lilliefors test for normality). 

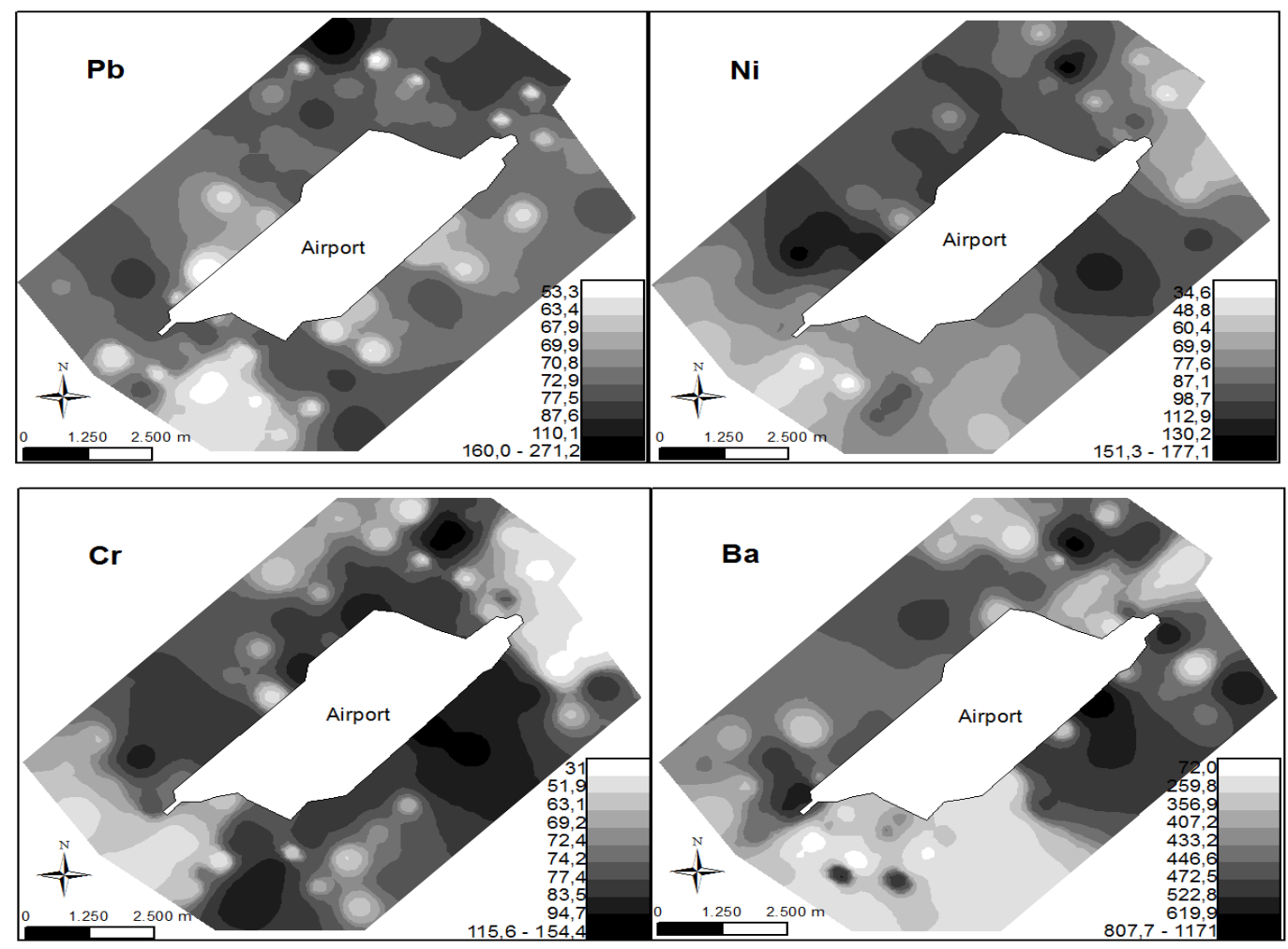

Figure 2 - Interpolated maps of the $\mathrm{Pb}, \mathrm{Ni}, \mathrm{Cr}$, and $\mathrm{Ba}$ total concentrations in the soils around the El. Venizelos airport.

\subsection{Cluster Analysis and Correlations}

As it is presented in Figure 5, two main clusters were distinguished. The metals included in the first main cluster are $\mathrm{Cr}, \mathrm{Ni}, \mathrm{Ba}, \mathrm{Mn}, \mathrm{Fe}$ and $\mathrm{Zn}$ while the second main cluster consists of $\mathrm{Pb}$ and $\mathrm{Cu}$. Within the first main cluster two clear sub-clusters observed indicating a strong relation between $\mathrm{Cr}$ and $\mathrm{Ni}$ and $\mathrm{Mn}$ and $\mathrm{Ba}$, respectively. A weak connection of Fe with the second sub-cluster is also noticed and a very weak association of $\mathrm{Zn}$ with the metals of the first main cluster is apparent. Considering that the smaller the linkage distance the stronger the relation between metals, it can be supported that the metals in each of the following $\mathrm{Cr}-\mathrm{Ni}, \mathrm{Ba}-\mathrm{Mn}$ and $\mathrm{Pb}-\mathrm{Cu}$ groups originated from the same source. The significant but weak correlations between the clay content and $\mathrm{Cr}, \mathrm{Ni}$ and $\mathrm{Mn}$ total concentrations ( $r$ values $0.34,0.36$ and 0.34 respectively, $p<0.05$ ) indicate that to some extent these metals derived from the soil's parent material. Clay content of the soils showed a significant correlation to the Fe total concentration $(r=0.60, p<0.05)$ that strongly supports the geogenic origin of Fe. The physicochemical characteristics of the studied soils did not correlate to $\mathrm{Ba}, \mathrm{Cu}, \mathrm{Zn}$ and $\mathrm{Pb}$ total concentrations, pointing to secondary soil enrichment by these metals probably due to atmospheric depositions. However, to robustly support any assumptions relative to the origin of the metals in the studied soils the bioavaliable / exchangeable forms of the metals must be determined and soil samples must be subjected to fractionation schemes, since heavy metals from anthropogenic sources could be more mobile than from geogenic sources (Burt et al., 2003; Gasparatos et al., 2015). 

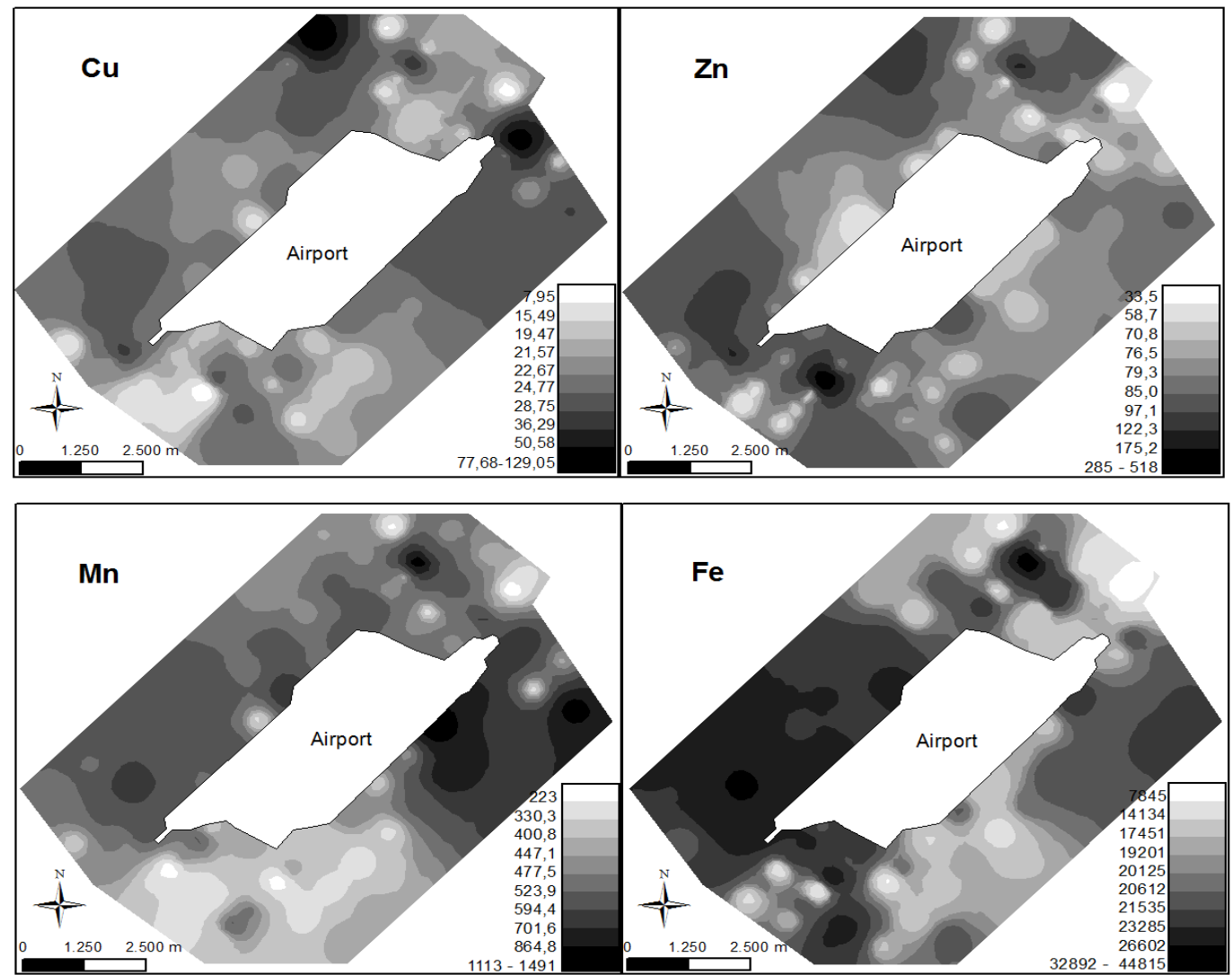

Figure 3 - Interpolated maps of $\mathrm{Cu}, \mathrm{Zn}, \mathrm{Mn}$, and $\mathrm{Fe}$ total concentrations in the soils around the El. Venizelos airport.

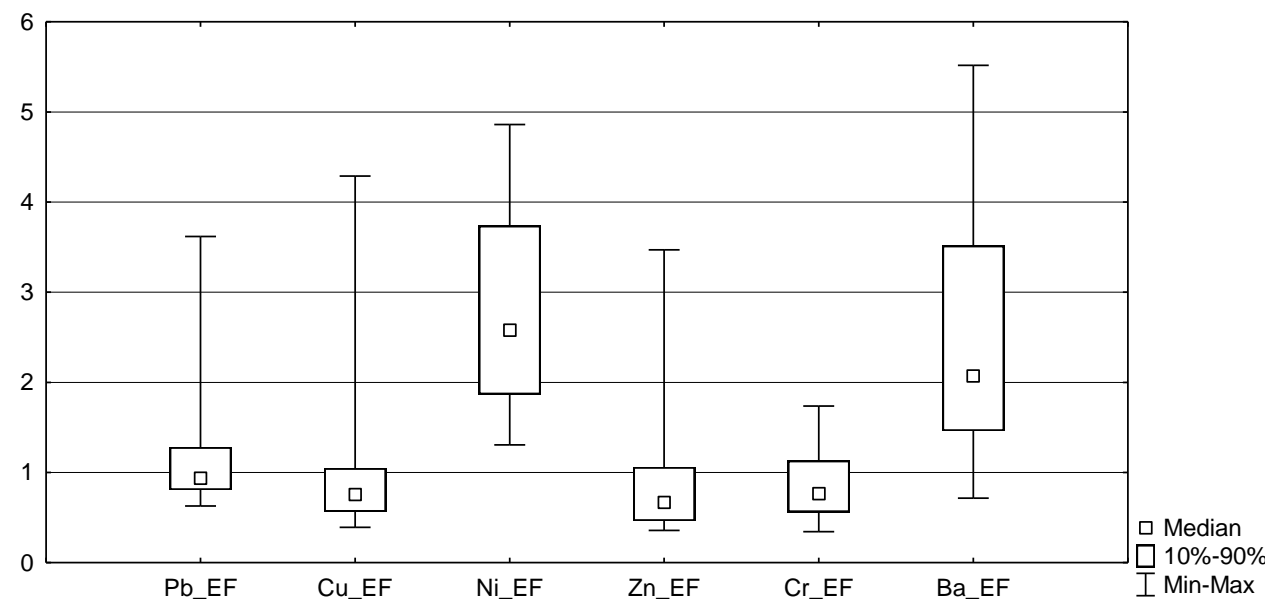

Figure 4 - Presentation of Enrichment Factors (EFs) statistics. 


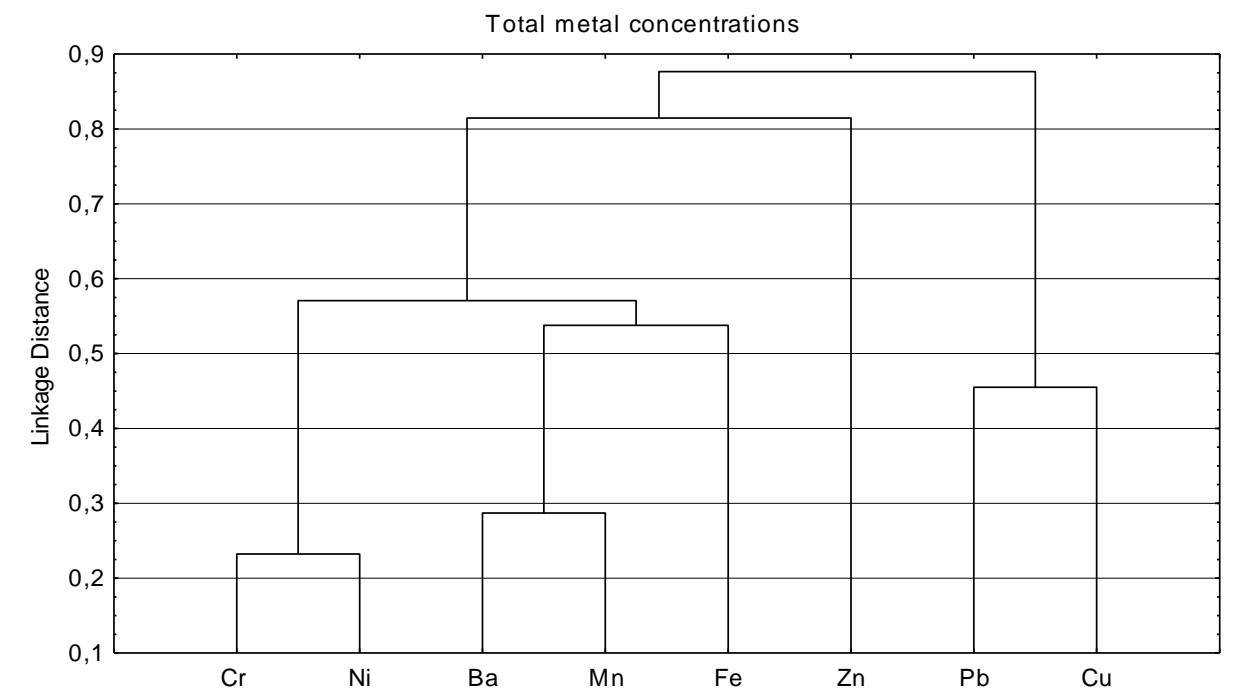

Figure 5 - Hierarchical clustering results (dendogram) of the total metal concentrations in the soils around the El. Venizelos airport.

\section{Conclusions}

This study attempted to record the levels of $\mathrm{Pb}, \mathrm{Cu}, \mathrm{Zn}, \mathrm{Ni}, \mathrm{Cr}, \mathrm{Ba}, \mathrm{Mn}$ and $\mathrm{Fe}$ in the soils around Athens International Airport after 13 years of airport operation. The mean metal concentrations were generally low but increased site specific $\mathrm{Pb}, \mathrm{Cu}$ and $\mathrm{Zn}$ and to a lesser extent $\mathrm{Ni}$ concentrations were determined. Cluster and correlation analyses results and Enrichment Factor values support the assumption of secondary accumulation of the above metals in the soils of the studied area due to aerial depositions. The dense airplane landing and taking off, the maintenance of the aircrafts and the traffic burden within and nearby the airport area may contribute to the observed site specific soil enrichment by $\mathrm{Pb}, \mathrm{Cu}$ and $\mathrm{Zn}$. Considering that this study is an assessment on preliminary data, more scientific research is needed to clearly distinguish between the sources of the metals present in the studied soils.

\section{References}

Al-Khashman, O.A. and Shawabkeh, R.A., 2009. Metal distribution in urban soil around steel industry beside Queen Alia Airport, Jordan, Environmental Geochemistry and Health, 31, 717-726.

Alloway, B.J. and Ayres, D.C., 1997. Chemical Principles of Environmental Pollution, Blackie Academic and Professional, London.

Bouyoukos, G.H., 1951. A recalibration of the hydrometer method for making mechanical analysis of soils, Agron. J., 43, 434-438.

Bretzel, F. and Calderisi, M., 2006. Metal contamination in urban soils of coastal Tuscany (Italy), Environ. Monit. Assess., 118, 319-335.

Burt, R., Wilson, M.A., Keck, T.J., Dougherty, B.D., Strom, D.E. and Lindahl, J.A., 2003. Trace Element Speciation in Selected Smelter-Contaminated Soils in Anaconda and Deer Lodge Valley, Montana, USA, Adv. in Environ. Res., 8/1, 51-67.

D'Amore, J.J., Al-Abed, S.R., Scheckel, K.G. and Ryan, J.A., 2005. Methods for speciation of metals in soils: a review, J. Environ. Qual., 34(5), 1707-1745.

Facchinelli, A., Sacchi, E. and Mallen, L., 2001. Multivariate statistical and GIS-based approach to identify heavy metal sources in soils, Environ. Pollut., 114, 313-324. 
Gasparatos, D. and Haidouti, C., 2001. A comparison of wet oxidation methods for determination of total phosphorus in soils, J., Plant Nutr. Soil Sc., 164, 435-439.

Gasparatos, D., Mavromati, G., Kotsovilis, S. and Massas, I., 2015. Fractionation of heavy metals and evaluation of the environmental risk for the alkaline soils of the Thriassio plain: a residential, agricultural, and industrial area in Greece, Environmental Earth Sciences, doi: 10.1007/s12665-015-4096-1.

Geochemical Atlas of Europe, 2005. Part 1: Background information, Methodology and Maps. Geological Survey of Finland.

Giannakopoulou, F., Gasparatos, D., Haidouti, C. and Massas, I., 2012. Sorption behavior of cesium in two Greek soils: effects of Cs initial concentration, clay mineralogy and particle size fraction, Soil and Sediment Contamination, 21(8), 937-950.

Kabata-Pendias, A. and Pendias, H., 2001.Trace elements in soils and plants, ( $3^{\text {rd }} e d s$.) Boca Raton, CRC.

Koulourasis, M., Aloupi, M. and Angelidis, M.O., 2009. Total metal concentrations in atmospheric precipitation from the Nothern Aegean Sea, Water Air Soil Poll., 209, 381-403.

Massas, I., Ehaliotis, C., Gerontidis, S. and Sarris, E., 2009. Elevated heavy metal concentrations in top soils of an Aegean island town (Greece): total and available forms, origin and distribution, Environ. Monit. Assess., 151, 105-116.

Massas, I., Ehaliotis, C., Kalivas, D. and Panagopoulou, G., 2010. Concentrations and availability indicators of soil heavy metals; the case of children's playgrounds in the city of Athens (Greece), Water Air Soil Poll., 212(1-4), 51-63.

Nelson, D.W. and Sommers, L.E., 1982. Total carbon, organic carbon and organic matter. In: Page, A.L., Miller, R.H. and Keeney, D.R., (eds.), Methods of soil analysis, Chap. 29. Madison: Soil Science Society of America.

Netherlands Ministry of Housing, Physical Planning and Environment (Netherlands MHPPE). 2000. Annexes circular on target values for soil remediation. The Netherland: MHPPE.

Olowoyo, J.O., van Heerden, E. and Fischer, J., 2013. Trace metals concentrations in soil from different sites in Pretoria, South Africa, Sustain. Environ. Res., 23, 93-99.

Papathanasiou, C., Makropoulos, C. and Mimikou, M., 2013a. The Hydrological Observatory of Athens: a state-of-the-art network for the assessment of the hydrometeorological regime of Attica, Proc. 13th International Conference on Environmental Science and Technology, 5-7 September, Athens, Greece (full paper submitted and accepted for oral presentation).

Papathanasiou, C., Massari, C., Pagana, V., Barbetta, S., Brocca, L., Moramarco, T., Makropoulos, C. and Mimikou, M., 2013b. Hydrological Study of Rafina catchment, Technical report for Action B1: Catchment Hydrological Modelling of the FLIRE Project (LIFE11 ENV GR 975).

Rao, P., Zhu, A., Yao, W., Zhang, W., Men, Y. and Ding, G., 2015. Sources and risk assessment of metal contamination in soils at the international airport of Shanghai, China, Toxicological \& Environmental Chemistry, 96, 1153-1161.

Ray, S., Khillare, P.S. and Kim, K.H., 2012. The Effect of Aircraft Traffic Emissions on the Soil Surface Contamination Analysis Around the International Airport in Delhi, India, Asian Journal of Atmospheric Environment, 6, 118-126.

Shrinivasa Gowd, S., Ramakrishna, M. and Govil, P.K., 2010. Assessment of heavy metal contamination in soils at Jajmau (Kanpur) and Unnao industrial areas of the Ganga Plain, Uttar Pradesh, India, J. of Hazard. Mater., 174, 113-121.

Swaine, D.J. and Micthell, R.L., 1960. Trace elements distribution in soil profiles, J. Soil Sci., 11(2), 347-368. 